\title{
EFFECT OF MACROPHYTE SPECIES ON SUBSURFACE FLOW WETLAND PERFORMANCE IN COLD CLIMATE
}

\author{
C. M. Ouellet-Plamondon ${ }^{1}$, J. Brisson ${ }^{1}$ and Y. Comeau ${ }^{2}$
}

\begin{abstract}
Horizontal subsurface flow constructed wetlands (HSSCW) allows organic matter and nitrogen removal of fish farm effluent prior to streams discharge. The effect of macrophyte species on HSSCW efficiency was tested in ten units in a greenhouse experiment, in summer and winter. Eight units were individually planted with Phragmites australis, Typha angustifolia, Phalaris arundinacea and Calamagrostis canadensis (two units per species) and the remaining two units were left unplanted. The units were fed with a reconstituted effluent made from trout farm sludge. The sludge was diluted to obtain an average of $15 \mathrm{~g} \mathrm{COD} / \mathrm{m}^{2} / \mathrm{d}, 3 \mathrm{~g} \mathrm{BOD} / \mathrm{m}^{2} / \mathrm{d}, 6 \mathrm{~g}$ $\mathrm{TSS} / \mathrm{m}^{2} / \mathrm{d}, 0.50 \mathrm{~g} \mathrm{~N} / \mathrm{m}^{2} / \mathrm{d}, 0.15 \mathrm{gP} / \mathrm{m}^{2} / \mathrm{d}$ and a resulting hydraulic loading of $3 \mathrm{~cm} / \mathrm{m}^{2} / \mathrm{d}$. Water quality was analysed in summer 2002 and winter 2003 for COD, BOD, TSS, TNK, $\mathrm{NH}_{4}{ }^{+}, \mathrm{NO}_{2}{ }^{-}+$ $\mathrm{NO}_{3}{ }^{-}$, TP and $0-\mathrm{PO}_{4}$. Planted units were at least $5 \%$ more efficient in pollutant removal than unplanted units in summer and at least $10 \%$ in winter. The increase in removal efficiency for planted units was small, mainly because of the low loading conditions of the fish farm effluent. TKN (96\% in summer and 88\% in winter) and COD (96\% in summer) removal were more efficient for Phragmites and Typha, the two species with large rhizomes. Phalaris was more efficient than the others with COD and BOD removal at 95\% in winter. Calamagrostis was the least efficient species, with the largest difference being for winter nutrient removal. It was also the species with the lowest belowground: aboveground biomass ratio, around 0.25 compared to above 2 for Typha. Units planted with macrophytes with large belowground biomass showed less seasonal variability.
\end{abstract}

KEYWORDS. Subsurface flow wetland, Macrophytes, Belowground biomass, Cold climate, Aquaculture effluent treatment

\section{INTRODUCTION}

Macrophytes are an active component of horizontal subsurface flow constructed wetlands (HSSFCW). They distribute and decrease current velocities. They increase contact time between water and plant surface area and surface area for attached microbial growth. They release oxygen and organic compounds to the rhizosphere. Macrophytes also assimilate nutrients a small fraction of nutrient. Their presence make constructed wetland a suitable solution for

\footnotetext{
${ }^{1}$ Institut de recherche en biologie végétale, University of Montréal, 4101 E Sherbrooke, Montreal (QC) HIX $2 B 2$ Canada

2 Department of Civil, Geological and Mining Engineering, Ecole Polytechnique, C.P. 6079, Succ. Centreville, Montreal (QC) H3C 3A7 Canada
} 
decentralised wastewater treatment applications (IWA, 2000). Moreover, HSSFCW can be integrated in the landscape and create wildlife habitat (Kadlec and Knight, 1996). Most studies comparing planted versus non-planted system showed a significant positive effect of plants on nutrients removal (IWA, 2000; Allen et al., 2002, Jing et al., 2002).

There is a need to diversify macrophytes species used in HSSFCW. Fast growth rate and establishment, tolerance to anoxic conditions, ability to form large monoculture and adaptation to local conditions (ex. cold hardiness) are biological attributes for HSSFCW application (IWA, 2000). There are some comparison studies, for different set of species, but they are not always conclusive (Bachand and Horne, 2000; Jing et al., 2002). Also, species applicability can change with latitude and local climate. Therefore, rigorous comparison studies with statistical replicates under controlled conditions are necessary to choose appropriate species for HSSFCW construction.

This study is part of a research project aiming to develop an appropriate treatment for fish farm effluent prior to stream discharged. The large quantity of phosphorus released in fresh bodies of water forces fish farm to adapt to new water quality standard. The system we are proposing to treat the concentrated effluent from the raceway decantation basin is a two-step procedure. First, HSSFCW removes organic matter and nitrogen. Secondly, a smaller non-planted unit filled with steel slag, a highly adsorbing substrate, removes phosphorus (Naylor et al., 2003).

The present experiment investigates the effect of species on HSSFCW efficiency. We compared the performance of Phragmites, Typha, Phalaris and Calamagrostis, in the treatment of a fish farm effluent in a greenhouse experiment, both during active and dormant growth season. We selected Phragmites, Phalaris and Typha, because they are the more common macrophytes used in constructed wetland (IWA, 2000). While Calamagrostis is not currently used, we selected it because it has the ability to form large monoculture looked for in HSSFCW applications.

\section{MATERIAL S AND METHODS}

Research took place in a greenhouse at the Botanical garden of Montreal. Controlled environment limited the number of variables interacting with the objectives of the study. The experimental system consisted of two $1500 \mathrm{~L}$ refrigerated bulk tanks to store the effluent, a central peristaltic pump, two redistribution basins with mixers, four peristaltic pumps, ten $1 \mathrm{~m}^{2}$ wetland units (1.23 m x $0.78 \mathrm{~m}$ x $0.32 \mathrm{~m})$ and two buckets after each wetland unit to collect the treated effluent. The wetland units were filled with a neutral $10-15 \mathrm{~mm}$ neutral substrate up to 3 $\mathrm{cm}$ from the edge. A 30-40 mm neutral river stone gabion at the inlet and the outlet facilitated water distribution and evacuation. Water table was kept $4 \mathrm{~cm}$ under the substrate surface. Eight units were individually planted with Phragmites australis, Typha angustifolia, Phalaris arundinacea and Calamagrostis canadensis (two units per species) and the remaining two units were left unplanted. Beds were planted on May 3, 2002 from collected rhizomes in fields on the south shore of the St-Lawrence River near Montreal. They were fertilized for the first month to ensure a proper start up. 
A reconstituted effluent from sludge collected in a silo acting as an anaerobic digester at a through-flow trout farm was used in the experiment. The sludge was diluted 50 times to obtain an average of $15.0 \mathrm{~g} \mathrm{COD} / \mathrm{m}^{2} / \mathrm{d}, 3.00 \mathrm{~g} \mathrm{BOD} / \mathrm{m}^{2} / \mathrm{d}, 6.00 \mathrm{~g} \mathrm{TSS} / \mathrm{m}^{2} / \mathrm{d}, 0.50 \mathrm{~g} \mathrm{~N} / \mathrm{m}^{2} / \mathrm{d}$ and $0.15 \mathrm{~g}$ $\mathrm{P} / \mathrm{m}^{2} / \mathrm{d}$, comparable to the silo supernatant. Fifteen litres were fed twice a day in each bed starting in June. The resulting hydraulic loading rate was $3.0 \mathrm{~cm} / \mathrm{m}^{2} / \mathrm{d}$ and the resulting voids hydraulic retention time was 3.6 days.

Results were collected during two periods, summer and winter. In summer, measurements were taken from July to October 2002 (macrophytes fully active, $\mathrm{T}_{\text {avg }}=22{ }^{\circ} \mathrm{C}$ ). In winter, measurements were taken from January to end of March 2003 (dormant season, above-ground portion previously harvested, $T_{\text {avg }}=7^{\circ} \mathrm{C}$ ). During these periods, the volume of the final effluent was measured three to four times a week to measure evapotranspiration. Efficiency calculation was based on mass balance between a sampling point in the storage bulk tank and a second one at the end of the wetland unit. The eight following water quality parameters were measured in compliance with the Standard methods 1998 (APHA, 1998): COD, BOD 5 , TSS, TNK, $\mathrm{NH}_{4}{ }^{+}$, $\mathrm{NO}_{2}{ }^{-}+\mathrm{NO}_{3}{ }^{-}$, TP and o- $\mathrm{PO}_{4}$. Analyses of variance (two-way-ANOVA) followed by multiple comparison of means according to Tukey's method were performed to test differences between treatments within each growth season.

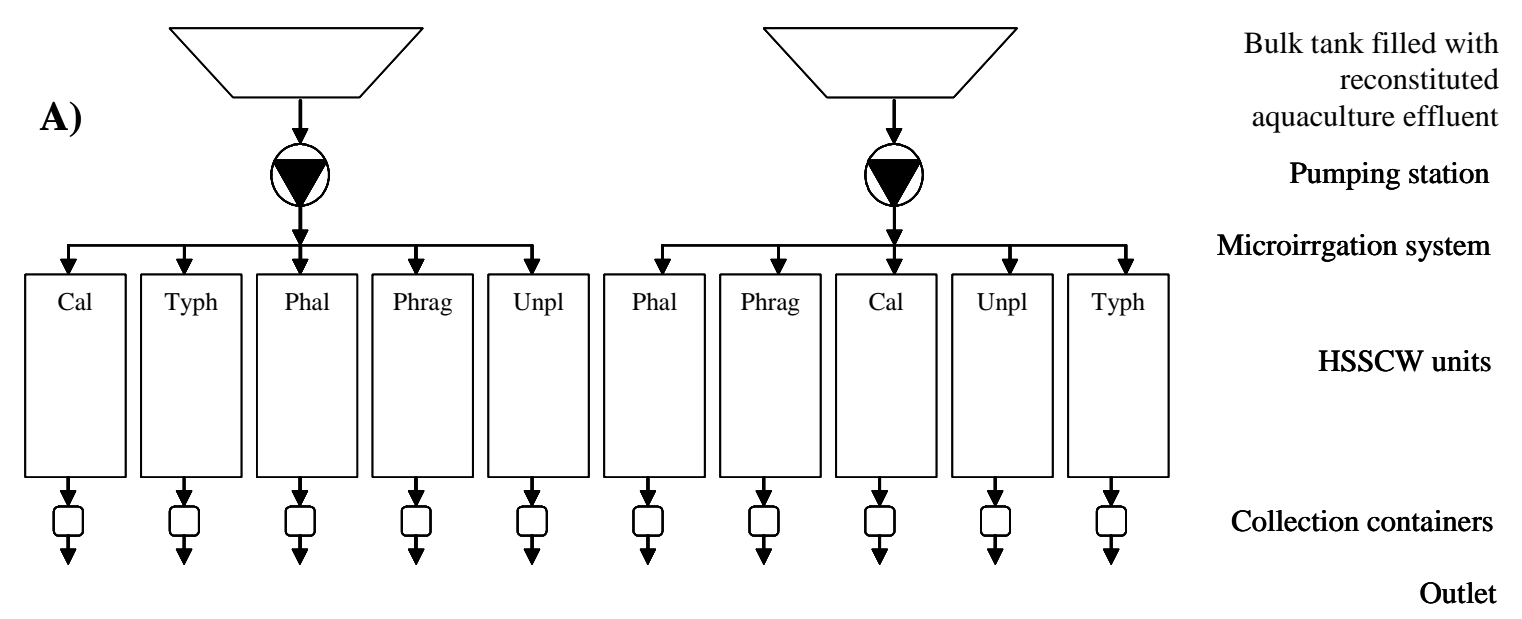



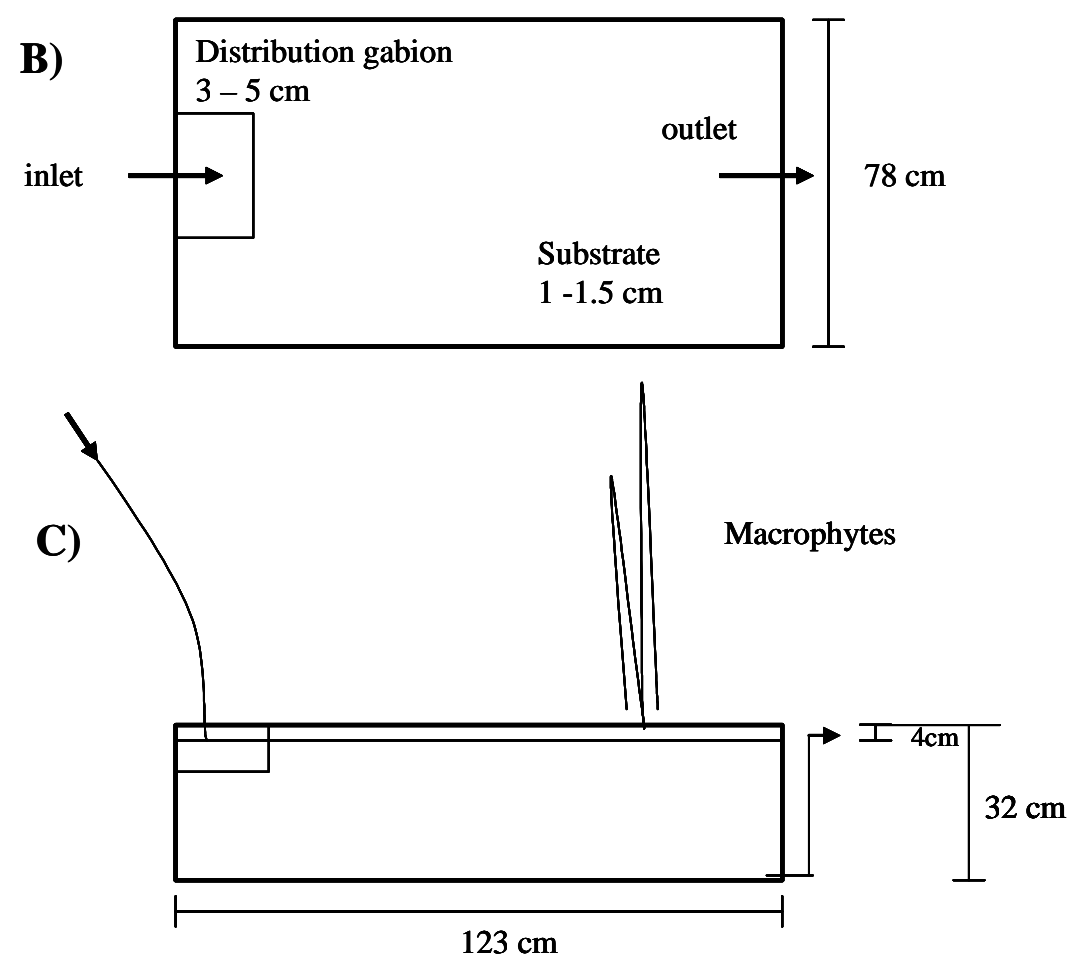

Figure 1. Experimental set-up A) Experimental layout (plan view) (Cal=Calamagrostis, Typh=Typha, Phal=Phalaris, Phrag=Phragmites, Unpl=Unplanted), B) Unit plan (view design), C) Unit design (cross section).

At the end of the summer period in 2002, the entire aboveground portion of the macrophytes was harvested and their foliage was analysed for nutrient content. Also, two $30 \mathrm{~cm}$ diameter cores of substrate were taken along the planted basins central axis, at $30 \mathrm{~cm}$ from the inlet and $30 \mathrm{~cm}$ of the outlet, to estimate belowground biomass. Both aboveground and belowground biomass were dried at $60^{\circ} \mathrm{C}$ for $72 \mathrm{~h}$ and weighted.

\section{RESULTS}

\section{Biomass}

The aboveground biomass was approximately $1 \mathrm{~kg} / \mathrm{m}^{2}$ for the first summer growing season for all species. Belowground biomass and, consequently, belowground: aboveground biomass ratio varied among species (Table 1). Although the variability of the results, Typha developed significantly more belowground biomass, followed by Phragmites and Phalaris. Calamagrostis developed considerably belowground biomass and it was concentrated near the surface of the bed. Typha produced significantly more rhizome compared to the three other species $(\mathrm{p}=0.0013)$. 
Table 1. Biomass data

\begin{tabular}{cccc}
\hline Species & $\begin{array}{l}\text { Aboveground } \\
\text { biomass }\end{array}$ & $\begin{array}{l}\text { Belowground } \\
\text { biomass }\end{array}$ & $\begin{array}{l}\text { Belowground: } \\
\text { Aboveground } \\
\text { biomass ratio }\end{array}$ \\
\hline \hline $\mathrm{g} / \mathrm{m}^{2}$ & $\mathrm{~g} / \mathrm{m}^{2}$ & $\mathrm{BG:AG}$ \\
\hline Phragmites & $1115+/-36$ & $946+/-356$ & $0.85+/-0.35$ \\
\hline Typha & $988+/-51$ & $2461+/-817$ & $2.47+/-0.70$ \\
\hline Phalaris & $1187+/-164$ & $1657+/-954$ & $1.35+/-0.62$ \\
\hline Calamagrotis & $1057+/-12$ & $256+/-147$ & $0.24+/-0.14$ \\
\hline
\end{tabular}

\section{Water Loss and Evapotranspiration}

During summer, there was a significant difference in evapotranspiration (Et) between unplanted and macrophytes units (Figure 1). Phalaris, Phragmites, Typha had significantly more evapotranspiration, followed by Calamagrostis and unplanted unit. There was no statistical difference in evapotranspiration in winter. It must be noted that evapotranspiration was probably higher than expected during winter due to a change in relative humidity between summer and winter. In the controlled greenhouse environment, vaporisation was used to decrease the ambient temperature in the summer. The relative humidity was higher in summer (60\% average) than in winter (RH 46 \%).

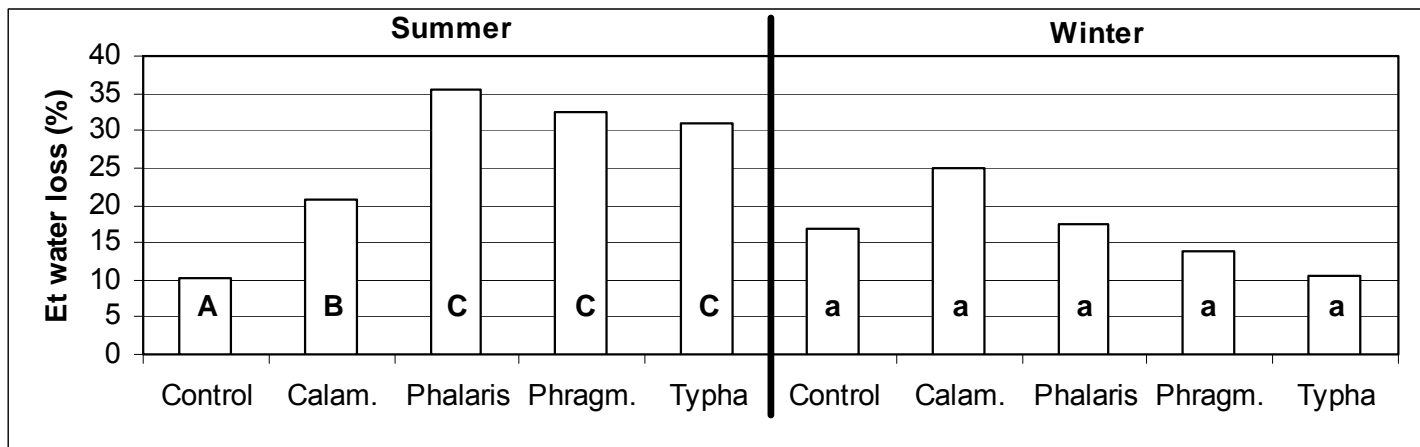

Figure 1. Effect of macrophyte species on summer and winter evapotranspiration ${ }^{3}$

\section{Organic matter}

During summer, macrophytes had a significant effect on COD removal ( $\left.\mathrm{p}_{\mathrm{s}}=0.0116\right)$ (Figure 2a). Phragmites, Typha and Phalaris were the most efficient and were statistically different from unplanted unit. Typha and Phragmites were also different from Calamagrostis. There was no significant different in summer $\mathrm{BOD}_{5}$ removal (Figure 2b). During winter, COD and $\mathrm{BOD}_{5}$ performance decreases were less important for planted units $\left(\mathrm{p}_{\mathrm{w}} \mathrm{COD}=0.0263 ; \mathrm{p}_{\mathrm{w}} \mathrm{BOD}_{5}=\right.$ 0.028). Phalaris was the best treatment and unplanted was the worst.

\footnotetext{
${ }^{3}$ Treatments with different letter code are significantly different according to multiple comparisons of means using Tukey’s method. Winter statistical tests were conducted independently from the summer.
} 

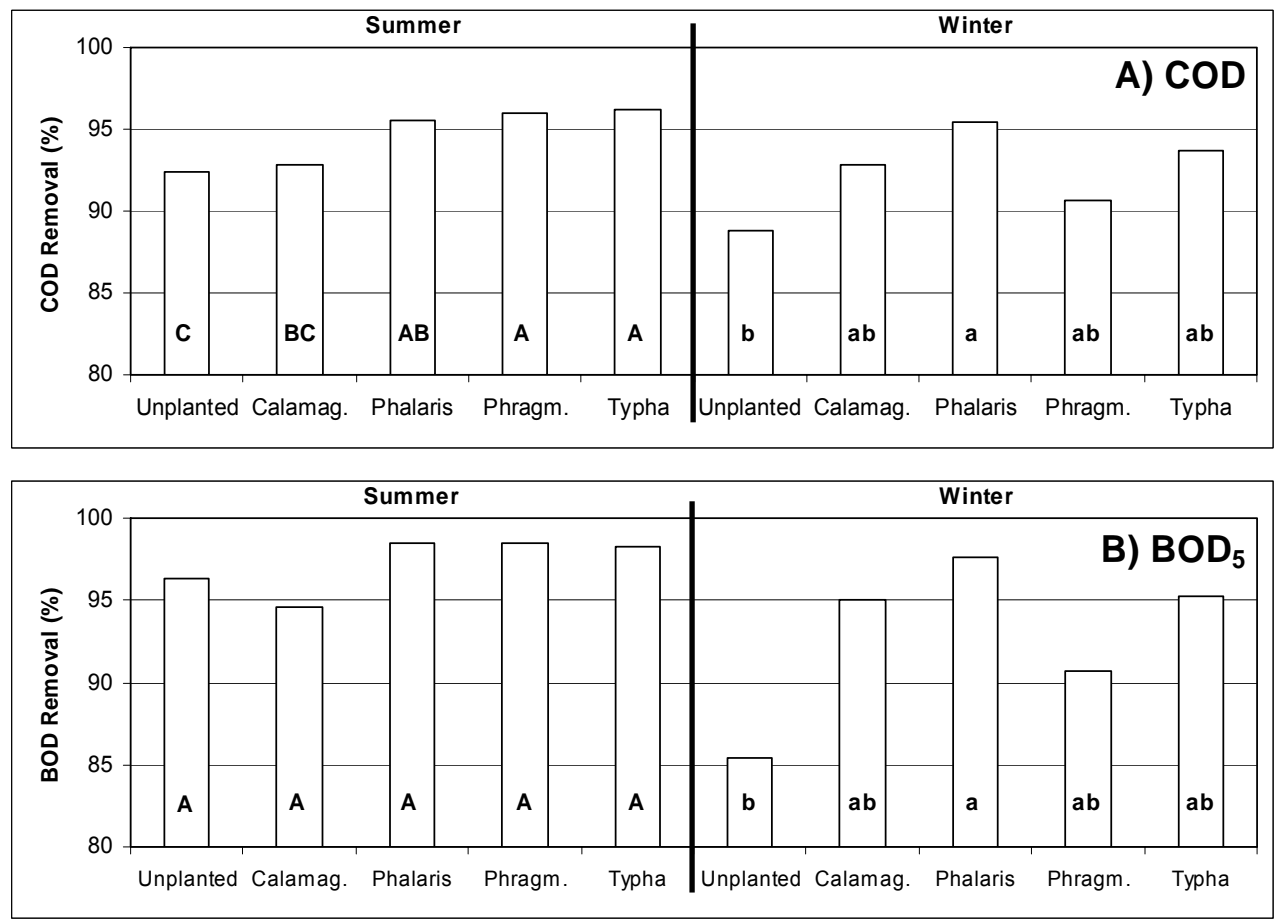

Figure 2. Effect of macrophyte species on summer and winter organic matter removal A) COD, B) BOD $_{5}$.

\section{$\underline{\text { Nutrients }}$}

Macrophytes showed their most significant effect for nitrogen removal $\left(\mathrm{p}_{\mathrm{s}}=0.0024 ; \mathrm{p}_{\mathrm{w}}=\right.$ 0.0255). Typha, Phragmites and Phalaris were more efficient than unplanted in both seasons (Figure 3a). Phalaris was not significantly different from Calamagrostis and from unplanted in winter also. Calamagrostis was more efficient than unplanted units, but the difference was not significant. There was a $10 \%$ efficiency drop in the winter. There was a statistical difference in macrophytes effect on phosphorus removal $\left(\mathrm{p}_{\mathrm{w}}=0.0068\right)$ (Figure $\left.3 \mathrm{~b}\right)$. Phalaris and Typha were different from Calamagrostis and unplanted. Phragmites was different from unplanted only, while Calamagrostis was not significantly different from all treatment. The winter performance decrease was more important for unplanted and Calamagrostis units.

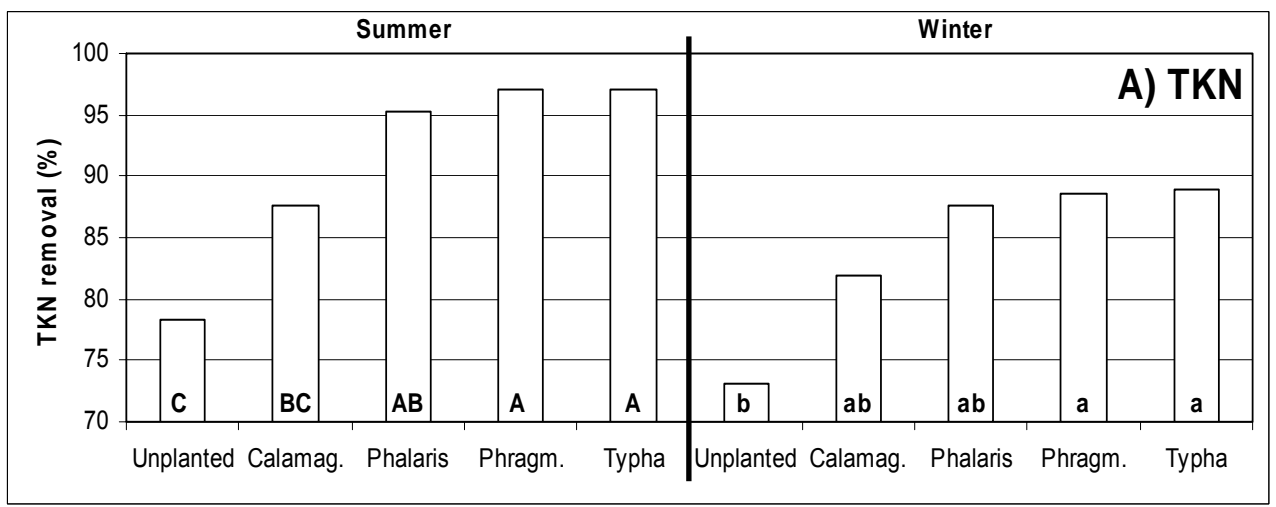




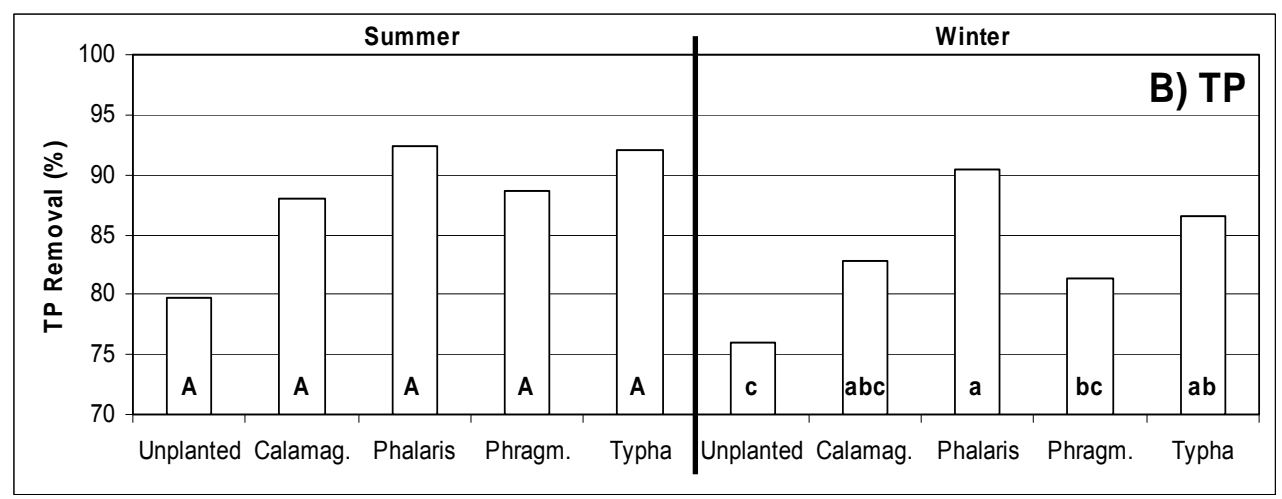

Figure 3. Effect of macrophyte species on summer and winter nutrient removal A) TKN, B) TP.

\section{Discussion}

\section{Effect of macrophytes}

This experiment confirmed the positive role of macrophytes on organic matter and nutrient removal (Kadlec and Knight, 1996). During summer, macrophytes increased evapotranspiration water lost, COD removal and nitrogen removal. During winter, macrophytes had an effect on COD, BOD 5 , phosphorus, TKN and $\mathrm{NH}_{4}$. TSS removal remained a physical process. Our results are consistent with the role of macrophytes for nitrogen removal and initial phosphorus removal (Tanner, 2001). HFSSCW fed with fish farm effluent are usually more efficient than average and the macrophytes increase in removal efficiency remained small. Lin et al. (2001) measured similar efficiencies in a HSSFCW experiment with similar loading and hydraulic retention time (HRT). Schulz et al. (2003) has similar results for TSS removal, but lower organic matter and nutrient removal for a HRT of less than a day. The observed high efficiency can also be explained by the controlled environment and by possible previous processing in the distribution tank. During summer, higher HRT caused by evapotranspiration improved the performance too (Bachand and Horne, 2000). The theoretical HRT was 3.6 day, but 5.4 day with the measured $33 \%$ evapotranspiration (relative humidity $60 \%$ ) in planted beds.

\section{Species differentiation}

Overall, we can say Typha, Phragmites and Phalaris had a similar removal and Calamagrostis was less efficient. The ranking of species is not definitive in the literature. Plant species does not make a difference in many studies (Bachand and Horne, 2000; Jing et al., 2002). Typha latifolia out-performed in some species comparison (Coleman et al., 2001), while in others its efficiency may decreased during winter (Allen et al., 2002). Typha angustifolia was very performant in our study. Typha angustifolia has also more reserve in rhizomes than Typha latifolia (Grace and Wetzel, 1982). It was also observed that Typha angustifolia was more tolerant to high ammonia level (Clarke and Balwin, 2002). There are other positive results with Phalaris trials (Vymazal et al., 2001b). Species differentiated more during winter. 
The enhancement of species differentiation in winter is consistent with other studies (IWA, 2000; Allen et al., 2002). Because the aboveground portion of the biomass was harvested, the difference is at the root level, largely attributed to the root structure and biomass allocation. The reliance on root biomass for nitrogen removal efficiency has been observed (Farahbakhshazad and Morrison, 1997). Our results showed a correlation between species efficiency and belowground biomass, even though belowground biomass results showed a greater variability due to sampling. Calamagrostis was the least efficient species, with the largest difference being for winter TKN and TP removal. It was also the species with the shallowest and the lowest belowground biomass. The low belowground biomass may also be explained by the large granulometry of the media $(10-15 \mathrm{~mm})$. Larger biomass was found in a sandy loam potting soil (Powelson and Lieffers, 1992). The belowground: aboveground biomass ratio was the lowest, around 0.25 compared to above 2 for Typha. This ratio has a potential to become a criteria for species selection. There were little differences between the three other species efficiency, all with larger belowground biomass. TKN (summer and winter) and COD (summer only) removal was more efficient for Phragmites and Typha. The belowground biomass of these two species consisted of large rhizomes. Typha had significantly more rhizome than Phragmites in our study. Phragmites was also reported to have more microorganisms per root surface area than Phalaris in bacterial count (Vymazal et al., 2001a). Phalaris was more efficient than the others at COD and $\mathrm{BOD}_{5}$ removal in winter. It developed a different root structure, more fibrous, less deep, less large rhizomes and its belowground biomass was between that of Typha and Phragmites. Phalaris is also known for a longer active period in number of days (USDA, 2004). Thus, our study suggests a relationship between the macrophyte function for the removal of organic matter and nutrient and its physiological root structure.

\section{Dormant season}

Temperature and macrophytes activity changed the seasonal performance. TKN removal had the more important seasonal decrease, followed by $\mathrm{TP}$ and $\mathrm{BOD}_{5}$ and COD. TKN removal efficiency was lower during winter for all treatments as reported by Werker et al. (2002). There was no uptake of nutrient in the dormant season. Temperature affects several biogeochemical processes which regulate nutriment removal in wetlands (Reddy and Burgoon, 1996; IWA, 2000). Bigger performance decreases related to temperature have been observed in outdoor facilities (IWA, 2000). The cause for the greater effect of macrophytes in winter is still a controversy. Allen et al. (2002) suggests it is because oxygen consumption for respiration decreases with temperature. The increased of oxygen solubility in winter provided more oxygen which improved transformation, while kinetics decreases (Kadlec and Knight, 1996).

\section{Ecological considerations}

The four species studied here have a potential to be invasive. Some region in the world, such as Australia, banned Phragmites introduction (Chambers and McCombs, 1994). Phragmites and Phalaris are known to be very active in the vegetation dynamics in the South west of Quebec (Lavoie et al., 2003). Phalaris and Typha angustifolia were also reported to replace native, perennial herbaceous, such as Calamagrostis canadensis, (Galatowitsch et al., 2000). Calamagrostis canadensis also has a potential to be invasive in disturbed open forest sites (Lieffers et al., 1993). Before selecting a species, local invasive status of the species should be determined. 


\section{CONCLUSION}

Macrophytes affect organic matter, nutrient removal and water balance, especially in winter. Our study showed an important link between physiological structure (belowground biomass, belowground: aboveground biomass ratio, rhizomes) and efficiency for subsurface flow wetland. We recommend these structures as criteria for species selection among native one. More studies are needed on the role of belowground plant structures on pollutant removal, especially in winter. We found no important differences between Typha angustifolia, Phragmites australis and Phalaris arundinacea and depending on local availability and invasiveness, all three species could be used. We do not recommend Calamagrostis canadensis under conditions comparable to ours because of its lower efficiency. This research confirms the important role of macrophytes in organic matter removal and nitrogen transformation in SSW, even in winter conditions when the plants are dormant.

\section{Acknowledgements}

We thank Denis Bouchard, Mourad Kharoune, Chris Donka, Laurent Côté, Martine Provost, Christine Galipeau, Sabina Tigges and Vincent Gagnon for technical support, Stéphane Daigle for statistical analysis, Florent Chazarenc for manuscript review and NSERC for financial support.

\section{REFERENCES}

Allen, W. C., P.B. Hook, J.A. Biederman and O.R. Stein. 2002. Temperature and wetland plant species effects on wastewater treatment and root zone oxidation. Journal of Environmental Quality 31(3): 1010-1016.

APHA. 1998. Standard Methods For the Examination of Water and Wastewater: including bottom sediments and sludges $18^{\text {th }}$ Edition . New York, N.Y.: American Public Health Association.

Bachand, P.A.M. and A.J. Horne. 2000. Denitrification in constructed free-water surface wetlands II: Effects of vegetation and temperature. Ecological Engineering 14: 17-32.

Chambers, J.M. and A.J. McCombs. 1994. Establishing wetlands plants in artificial systems. Water Science and Technology 29 (4): 79-84.

Clarke, E. and A. H. Baldwin. 2002. Responses of wetland plants to ammonia and water level. Ecological Engineering 18 (3): 257-264.

Coleman, J., K. Hench and K. Garbutt. 2001. Treatment of domestic wastewater by three plant species in constructed wetlands. Water, Air, and Soil Pollution 128 (3-4): 283-295.

Farahbakhshazad, N. and G. M. Morrison. 1997. Ammonia Removal Processes for Urine in a Upflow Macrophyte System. Environmental Science and Technology 31: 3314-3317.

Galatowitsch, S.M., D.C. Whited, R. Lehtinen, J. Husveth and K. Schik. 2000. Environmental Monitoring and Assessment 60: 121-144.

IWA. 2000. Constructed Wetland for Pollution Unplanted Processes, Performance, Design and Operation. Scientific and Technical Report No. 8.g London, UK: IWA Publishing. 
Jing, S., Y. Lin, T. Wang and D. Lee. 2002. Microcosm Wetlands for Wastewater Treatment with Different Hydraulic Loading Rates and Macrophytes. Journal of Environmental Quality 31(2): 690-696.

Kadlec, R.H. and R.L. Knight. 1996. Treatment Wetlands. Boca Raton, FL: CRC Press, Inc.

Lavoie C., M. Jean, F. Delisle and G. Létourneau . 2003. St. Lawrence River wetlands: A spatial and historical analysis. Journal of Biogeography 30: 537-549.

Lin, Y., S. Jing and D. Lee. 2002. Nutrient removal from aquaculture wastewater using a constructed wetlands system. Aquaculture, 209: 169-184.

Naylor, S., J. Brisson, M.A. Labelle, A. Drizo and Y. Comeau. 2003. Treatment of fresh fish farm effluent using CWSs - The role of plants and substrate. Water Science and Technology 48(5): 215-222.

Powelson, R.A. and V. J. Lieffers. 1992. Effect of light and nutrients on biomass allocation in Calamagrostis canadensis. Ecography 15: 1 (1992).

Reddy, K.R. and P.S. Burgoon. 1996. Influence of temperature on biogeochemical processes in constructed wetlands - Implications to wastewater treatment. Paper presented at the Symposium on Constructed wetlands in Cold Climates, June 4-5, 1996, Niagara-on-theLake, Ontario.

Schulz, C., J. Gelbrecht and B. Rennert. 2003. Treatment of rainbow trout farm effluents in constructed wetland with emergent plants and subsurface horizontal water flow. Aquaculture 217: 207-221.

Tanner, C.C. 2001. Plants as ecosystem engineers in subsurface-.treatment wetlands. Water Science and Technology 44(11-12): 9-17.

USDA, NRCS, 2004. The Plant Database, Version 3.5. National Plant Data Center, Baton Rouge. Available on http://plants.usda.gov (search on 2003-04-10).

Vymazal, J., J. Balcarová and H. Doušová. 2001a. Bacterial dynamics in the sub-surface constructed wetland. Water Science and Technology 44 (11-12): 207-209.

Vymazal, J. 2001b. Constructed wetlands for wastewater treatment in the Czech Republic. Water Science and Technology 44 (11-12): 369-374.

Werker, A.G., J.M. Dougherty, J.L. McHenry and W.A. Van Loon. 2002. Treatment variability for wastewater treatment design in cold climates. Ecological Engineering 19: 1-11.

Yang, L., H.T. Chang and M.L. Huang. 2001. Nutrient removal in gravel- and soil- based wetland microcosms with and without vegetation. Ecological Engineering 18: 91-105. 